Egyptian Journal of Archaeological and Restoration Studies
An international peer-reviewed journal published bi-annually
www.ejars.sohag-univ.edu.eg

Original article

\title{
UN-TRANSMITTED SPELLS INTO THE POST-UNIS OLD KINGDOM PYRAMID TEXTS
}

\author{
Abd El-Sattar, I. \\ Egyptology dept., Faculty of Archaeology, Fayoum Univ., Fayoum, Egypt \\ E-mail address: eae01@fayoum.edu.eg
}

\begin{tabular}{|c|c|}
\hline Article info. & EJARS - Vol. 10 (1) - June 2020: 29-42 \\
\hline Article history: & Abstract: \\
\hline Received: $24 / 6 / 2019$ & The pyramid texts are funerary spells which were found in eleven \\
\hline Accepted: $28 / 11 / 2019$ & pyramids of old kingdom kings and queens. This paper deals with \\
\hline Doi: $10.21608 /$ ejars.2020.98960 & $\begin{array}{l}\text { the phenomenon of excluding some spells of the old kingdom pyramid } \\
\text { texts after their first attestation. This study assigns the term "Un- } \\
\text { transmitted spells" to identify these spells which were attested in } \\
\text { a certain pyramid while not reselected once again in the other } \\
\text { pyramids. The paper focuses on those of Unis pyramid, which has } 38 \\
\text { un-transmitted spells, trying to answer two essential questions: }\end{array}$ \\
\hline Keywords: & why these spells emerged only once in the pyramid of Unis and \\
\hline New philology & $\begin{array}{l}\text { were not transmitted or reselected Into the other old kingdom } \\
\text { pyramids? Were these spells transmitted or reselected and became a }\end{array}$ \\
\hline $\begin{array}{l}\text { Old kingdom } \\
\text { Pyramid texts }\end{array}$ & part of the re-contextualization program after the old kingdom or \\
\hline Unis & $\begin{array}{l}\text { not? The study suggests three reasons for the phenomenon in } \\
\text { question depending on the investigation of the Pyramid Texts }\end{array}$ \\
\hline Un-transmitted spells & editing during the old kingdom. \\
\hline
\end{tabular}

\section{Introduction}

Since the discovery of the pyramid texts up to now, most of the pyramid texts studies focused on where these texts originated and how they developed. In addition, the orientation of its reading - from the entrance to the funerary chamber [1-2] or from the funerary chamber to the entrance [3]was the principle for a long debate. Most of Egyptologists agreed that the orientation of the hieroglyphs is closely connected with the direction of reading and the layout of the texts. In that respect, they pointed that the location of spells physically plays a role in the choice and the meaning of each text, and namely, the relation between the texts' corpus and its location on the walls [1-11]. Recently, the pyramid texts studies began to concentrate on how the genres of these texts were transmitted or reproduced through space and time. These studies have tried to identify the mechanisms of these texts' transmission or reproduction, and the criteria of this process [12-25]. Moreover, those studies have been dominated by three philological disciplines: The textual criticism, the literature criticism, and the new philology [26-28]. The first one focuses on the reconstruction of a hypothetical archetype/Vorlage of the surviving texts' variants. The second is devoted to studying the interpretation of the text, its characteristics, and the development of its genres. The third one considers the intellectual and the cultural environment of the texts' editors "manuscript culture" are important factors that influence the re-contextualization program of the texts. The text had a single meaning and its later variants should be regarded through the prevailing culture. In other words, the new philology identifies any change appearing during the process of text transmission as a part of the new text culture [5,16,23-24]. 


\section{Research Methodology}

The phenomenon of why some texts (spells) are not reselected or transmitted from a pyramid to another one in the old kingdom is a part of the transmission process which could be subjected to the hypothesizes of the textual criticism, the literature criticism, and the new philology. Accordingly, this paper attempts to answer two essential questions; why these spells emerged only once in Unis' pyramid texts corpus and were not transmitted or reselected into the other old kingdom pyramids corpora? Were these spells transmitted or reselected and became a part of the contextualization program after the old kingdom or not?

\section{A Glimpse on the Organization of the Pyramid Texts}

The old kingdom pyramid texts' arrangement and their topographical distribution was and still the subject of investigation. The pyramid texts compose of spells, clustered in genres that have the common character and are thematically homogenous [22]. The pyramid texts of Unis were arranged by Osing in groups [9], while Allen subdivided them to sequences [6]. Previously, Altenmüller classified the pyramid texts and used the term Spruchfolge to refer to clusters of spells [29]. On the other hand, the complete study of the topology and the disposition of the old kingdom pyramid texts were explored by Hays who broke them down into groups; each containing more than one sequence and subsequence (recurring series) [30-31]. Both Osing and Allen organized the spells based on the theme and location, while Hays essentially depended on the homogenous theme, and the location became secondary.

\section{The Old Kingdom Un-transmitted Pyramid Texts}

What is opted by the author for the term "Un-transmitted Spells" are those which uniquely attested in such a pyramid and they were not reselected once again in the other old kingdom pyramids. The phenomenon of the un-transmitted spells is explicit in the pyramid texts of Teti which has 36 spells that were not transmitted to his postpyramids. Only two of them were transmitted to the middle kingdom and were excluded thereafter. The pyramid texts of Unis include 227 spells. The editors of his post-pyramids reselected 189 spells and excluded 38 spells as follows: PT 200, PT 204, PT 209, PT 226, PT 228-232, PT 234-239, PT 241243, PT 247-252, PT 260, PT 263. PT 275-279 (except PT 277), PT 294, PT 300, PT 313-315, PT 317, and PT 319320. These spells, except for PT 200, were transmitted after the old kingdom and they were integrated and rearranged into new compositions. They were also modified in the content, the orthography, the size of the genres, and the size of each spell. Therefore, their later reviving may offer additional help to answer the hypothesized questions of this paper. In this current study, these spells will be classified into many groups based on their location and the theme that was classified by Osing, Allen, and Hays. Consequently, they will be identified, by the author, from $\mathbf{G 1}$ to $\mathbf{G 4}$ which can be tabulated in tab. (1).

Table (1) Unis' Un-transmitted spells into his post-old kingdom pyramid texts

\begin{tabular}{|c|c|c|c|c|}
\hline $\begin{array}{l}\text { The } \\
\text { Group }\end{array}$ & $\begin{array}{l}\text { Unis' un- transmitted spells } \\
\text { into the post-pyramids }\end{array}$ & $\begin{array}{c}\text { The } \\
\text { Location }\end{array}$ & The whole genre & $\begin{array}{l}\text { Unis' transmitted } \\
\text { spells into the post- } \\
\text { pyramids }\end{array}$ \\
\hline G-1A & $\begin{array}{l}\text { PT 226, 228, 229, 230, 231, } \\
232,234,235,236,237,238, \\
239,241,242,243\end{array}$ & $\mathrm{~W} / \mathrm{B} / \mathrm{Wg}$ & PT 226-243 & PT 227, 233, 240 \\
\hline G-1B & PT 275,276 & W/A/Eg & PT 273-276 & PT 273, 274 \\
\hline G-1C & PT 278, 279, 294, 300 & W/A/E & PT 277-301 & $\begin{array}{c}\text { PT } 277, \mathbf{2 8 0 - 2 9 3 ,} 295- \\
\mathbf{2 9 9}, \mathbf{3 0 1}\end{array}$ \\
\hline G-2A & PT 204, 209 & $\mathrm{~W} / \mathrm{B} / \mathrm{Eg}$ & $\begin{array}{l}\text { PT 204-205, 207, } \\
209-212\end{array}$ & PT $205,207,210-212$ \\
\hline
\end{tabular}




\begin{tabular}{llccc}
\hline G-2B & PT. 200 & W/P/N & PT.199, 32, 23, 25, 200 & PT 199, 32, 23, 25 \\
G-3A & PT 247, 248, 249, 250, 251, 252 & W/A/Wg & PT 247-253 & PT 253 \\
G-3B & PT 260 & W/A/W & PT 254-260 & P 254-259 \\
G-3B & PT 263 & W/A/S & PT 260-272 & PT 261-262, 264-272 \\
G-4A & PT 313, 314, 315, 317 & W/C/W & PT 313-317 & PT 316 \\
G-4B & PT 319, 320 & W/C/E & PT 318-321 & PT 318, 321 \\
\hline
\end{tabular}

\subsection{Group 1A -PT 226, PT 228-232, PT 234-239, and PT 241-243:}

Group 1A includes the serpent spells [32, 33 ] and the other hostile beings which are classified by Osing to two groups; Group A: the genre PT 226-243, consists of 18 spells, which entirely attested only in the pyramid of Unis, filling the west gable of his burial chamber $(\mathrm{W} / \mathrm{B} / \mathrm{W})$, and Group A2: the genre PT 276-299 which occupy most of the east wall of his antechamber (PT 277-299- W/A/E) and a part of its gable (PT 276- W/A/Eg) [9]. The first genre PT 226-243 is distinguished by Allen as a sequence $(\mathrm{H})$ [6], while Hays designates it as section (K1), a part of the Group $(\mathrm{K})$ by which it is identified as Apotropaia [30]. Also, additional genre PT 375-399 was added to the pyramid texts corpora of the post-Unis pyramids. It is also identified by Hays as the apotropaic texts against the serpent that compose with the genre PT 276-299 Section (K2ab). This section is inscribed above the right hand of the entrance of the serdab, occupying the south part (right-hand) of the east wall of Pepi I's antechamber, and the north part (left-hand) of east walls of the antechambers of Teti, Merenre and Pepi II [34-36]. The genre PT 226-243 was not entirely transmitted to the pyramids of Unis' successors, except three spells that were isolated, discretely amalgamated into the post-Unis pyramid texts corpora and integrated into the genre PT 276-299. The incorporation of these three spells into the post-Unis pyramid texts was accompanied by the change of their location. The first one (PT 227) is located on the east wall of the antechamber of both Pepi I and Pepi II, while the second one (PT 233) is placed on the east wall of the antechamber of Pepi I, Pepi II. The third one (PT 240) is commonly attested in the post-Unis pyramids and it is located on the east wall of the antechamber of Teti, Pepi I, Merenre and Pepi II [34,36]. Recently, few words of PT 245-246 were discovered by the french mission in the pyramid of the queen Behnw [37]. The transmission of three spells from this genre to the post-Unis pyramids reflects, as suggested by some Egyptologists, the synecdoche principle i.e. these short sequences are made to represent the whole genre [5,16,22,23]. It is noted that the location of the serpent spells in the post-Unis pyramids was often restricted to the east wall of the antechamber and its gable, while the old one- - the west gable of the burial chamber-was abandoned. In Pepi I's pyramid texts corpus, the compilation process of the serpent spells continued and extended to the corridor, ascending corridor, and the vestibule (PT 538, PT 550-51 A-D). Basically, the generative process of editing and compilation the serpent spells started in the pyramid texts corpus of Teti who added 25 new spells (PT 375-399), and they extended to the post-Teti pyramid texts corpora, particularly in Pepi I's pyramid texts corpus who added 32 new spells (PT 499500, PT 501A-D, PT 502A-Q, PT 1035 , PT 1043) marked by developing a new location in the north [38]. There is consensus among the Egyptologists that the purpose of the genre PT 226-243 is to protect the deceased king from the snakes and other reptiles. They are non-ritualistic spells, spoken in the first person, and recited by the deceased king himself as magical spells $[6,32]$. The editors of the post-Unis pyramid texts corpora marginaalized the genre PT 226-243, while it was indispensable in the middle kingdom. At this point, the editors of the middle kingdom did not only revive this genre, but they also explained its meaning. They frequently attributed its introductory spell PT 226 to the title $r$ ? $n(j)$ hssf rrk $m$ hr.t nt $r$ (Utterance 
for driving away $r r k$-serpent in the necropolis) [17,29-30]. Also, this meaning is dealt with by CT.885 that states hsf rrk $h^{c} R^{c}$ (Driving away rrk-serpent so that $R^{\top}$ may shine) (CT.VII. $94 \mathrm{~m}$ ). Furthermore, the occurrence of this genre extends from El-Qatta and Saqqara to Lisht, Meir, and Thebes. In the burial chamber of the tomb of $N h 3$ (Q1Q) at El-Qatta, this genre is subdivided into two continuous sequences PT 226-227 and PT 229-240 which are located on the east wall of this chamber [39-41]. Worthy of note, the genre PT 226-243 was locally varied in the middle kingdom pyramid texts. Its entire copy occurred twice in the burial chambers of both $s 3-h t-h r-j b j$ [39] and sk-wsht [17] in Saqqara cemetery from which the largest number of its copies come. At Lisht, the tomb of $s-n$-wsrt- ${ }^{-} n h$ contains the whole spells of this genre [5,42], while the lid of the coffin (L1NY) of hty has PT 226241, PT 243 and lacks PT 242 [5,17]. On the other hand, the other sources texts from Lisht have just a few spells $[17,43]$. Likewise, the sources texts of Meir [17, 39,44] and Thebes [17,39] incorporate fewer spells that are continuously or discontinuously arranged in shorter sequences. What should be noted is that these short sequences consist of one or more spells; particularly the initiatory spells of this genre PT 226, PT 229, PT 226-228, PT 226-230, and PT 226-231. After the middle kingdom, the genre PT 226-243 was abandoned until it was reused once again in the Saite Period. Hussein noted that the "Grabpalasten" of the Saite period at Asasif eliminated this genre except for the tomb of P3-dj-Imn-( $m$ )-jpt (TT33) in which it was integrated with the genre PT 276-299 in a single composition [22-47]. Both the two genres are located on the same wall, as $s-n-w s r t-{ }^{-} n h$ did, under the title $r 3 n$ hsf $r r k m$ hr.t ntr [45-46] that was previously attributed to the introductory spell of the genre PT 226-243 in the middle kingdom. What worthy noted is that hr.t ntr is substituted with jmn.t (the west) as attested in the tomb of Psmtk at
Saqqara. Additionally, Hussein concluded that the transmission of the genre PT 226243 to the Memphite and Heliopolitan shaftombs of the Saite period was dynamic concerning the inclusion and the exclusion of the spells in short sequences that were rearranged, like the middle kingdom copies, in interrupted and uninterrupted sequences [47]. The short sequences PT 227-229, PT 233, PT 242, and PT 239 in this order are more common in the saite period with the fact that no two tombs contain the same series of spells [22]. To round off, reselecting short sequences of spells from the genre PT 226-243 was a mutual feature in both the middle kingdom and the late period. In the textual program of reselecting the pyramid texts in the middle kingdom and the late period, this genre is often associated with the genre PT 213-219 which thematically center on the emerging from the Duat. It is also connected with the spells of offering ritual PT 62-81 and PT 204-205; the spells of censing and libation PT 23, PT 25, and PT 35. Obviously, the preceding spells constitute a part of the old textual program of Unis' burial chamber and the passage between the burial chamber and the antechamber. At this point, it could be suggested that reselecting a specific genre may depend on its original location as well as its relationship with the other genres. It means that the genre does not only connect with its original location but also it has a cohesive correlation with specific genres with which they perform a definite role and represent one unit. If a genre loses its original location and its relationship with the other genres, it may be excluded. This suggestion is supported by the hypothesis of Hussein who argued that the meaning and the purpose of the genre PT 226-234 go beyond the king's protection to a cosmogonic and mythologic meaning [22,48]. According to his argument, this genre signifies the mythological struggle between $R^{\top}$ and the chaos serpent ${ }^{\prime} p p$ that takes place in the water (Abyss). Worthy of mention, the genre PT 226-243 has already various references of this struggle, while it became apparent in its middle kingdom title $r^{3} n(j)$ 
hsf rrk $m$ hr.t ntr (Utterance for driving away $r r k$-serpent in the necropolis). Since this struggle connected with the necropolis or the west and the abyss, the location of this genre on the west gable of Unis' burial chamber is very appropriate to correspond with the cosmogonic west. This last explanation, as well as reselecting short sequences of this genre after the old kingdom, may answer the question of why the editors of the post-Unis pyramid texts corpora marginalized this genre, and why they reused only three spells from it. Depending on the last discussion, the genre PT 226-243 is connected with the west-gable of the burial chamber which was occupied in Unis post-pyramids by the spells of the king's ascension to the sky as well as the pyramid texts of Nut $[5,30,49]$ rather than the serpent spells. As a result, the change of this genre's location as well as the loss of its cohesive relation with the other genres of the burial chamber explains the reasons for its disappearance in post-Unis pyramids.

\subsection{Group 1B -PT 275-276}

Group 1B consists of the two spells PT 275-276. They are a part of the genre PT 273-276 which is located on the east gable of Unis' antechamber. It is organized by Osing in group (D) [9], while it is classified by Allen as a part of Sequence (F2), which begins with PT 273 and ends with the PT 276 [6]. Hays arranges these spells in Section (K2b), identifying them as Apotropaia [30]. Only the two spells PT 273-274 of this genre, known among the Egyptologists as the "cannibal hymns spells", were transferred to the pyramid texts of Teti. After the old kingdom, the two spells PT 275-276 were transmitted, as components of the genre PT 267-291, to the east wall of the burial tomb of $s n$ wsr.t- ${ }^{-} n h$ [42]. After the middle kingdom, PT 275 was eliminated, while PT 276 was once attested in the tomb of $P 3-d j-$ Imn-(m)-jpt (TT33) as a part of the genre PT 276-299 (serpent-spells) [23]. The two spells PT 275-276 connected with the so-called "cannibal hymns spells" PT
273-274 [50-53] which describe the king as the one who swallows and devours his enemies and his kin; his mother and father, the gods and the $a k h u$, in order to obtain their powers. According to Allen viewpoint, the two spells PT 273-274 confirm the king's ascension from the primeval water $N u$, crossing its gate to the sky [6]. In PT 275, the king is identified with Sobek $w r m$ s d.t to overcome the dangers in this water. According to Allen, the genre PT 276-299 which is located on the same wall seems to play the same role of protecting the king during his ascension to the sky [6]. As a result, PT 275 could be described as a "protectivespell" with a mythological origin. During their editing process, the editors of Teti's pyramid texts corpus eliminated the two spells PT 275-276 and rearranged PT 273274 after the new genre of serpent-spells PT 375-399 and some spells of the genre PT 277-299. Add to, the genre PT 277299 in the post-Teti pyramid texts corpora connected with the spells of offeringgroup $(\mathrm{H})$ according to Hays [30]- rather than the spells of the king's ascension. Both the editors of Teti and his successors rearranged the spells of the genre PT 273276 and their relationship with the other genres by exclusion and addition. The editors of Teti pyramid texts excluded PT 275-276 and integrated PT 273-274 with PT 375-399 (serpent-spells) as a genre of the king's protection, while the editors of Teti's successors excluded PT 273-276 and rearranged PT 277-299 together with the offering spells, probably to protect the serdab and the offering [33].

\subsection{Group 1C - PT 278, PT 279, PT}

\section{4, and PT 300}

Group 1C contains the spells PT 278, PT 279, PT 294 and PT 300 which are located on the east wall of Unis' antechamber. These spells are the members of the genre PT 277-301 which is classified by Osing as a part of group (D) [9]; while Allen distinguishes them in Subsequence (F3) [6]. Hays arranges them in section 
(K2) [30]. With reference to the above, Osing classifies PT 277-299 as group A2 (serpent-spells) which are completely different in theme from PT 300-301. Apart from PT 278, PT 279, PT 294, and PT 300 , the other spells of this genre were transmitted to the post-Unis pyramid texts corpora with the same location. In the middle kingdom, this genre is entirely attested in the tomb of $s-n-w s r t-{ }^{-} n h$ [42], while PT 300 is attested in the burial chamber of $W s r$ at Lisht $[16,43]$. In the new kingdom, the entire genre PT 277-301 were abandoned, while it was attested together with the genre PT 223-246 in a single composition in the late period tomb of P3-dj-Imn-(m)-jpt (TT33) [23]. They are located on one wall under the title $r 3$ $n$ hsf $r r k m$ hr.t $n t r$; the middle kingdom title of the introductory spell of the genre PT 226-243. The exclusion of some spells of the genre PT 277-299 was due to the editorial activities after Unis. The editors integrated them with the other homogenous ones. The un-transmitted spells of this genre were replaced, after Unis, by the spells of the new ones which are similar in content and theme i.e. PT 375- 399, PT 1035-1043, and PT 502 A-H [30]. On the other hand, PT.300 was undoubtedly excluded because of its heterogeneous theme.

\subsection{Group 2A -PT 204 and PT 209}

Group 2 A composes of PT 204 and PT 209. They are a part of the genre PT 204-205, PT 207, PT 209-212, which is exclusively inscribed on the east gable of Unis' burial chamber. Noticeably, the only source of this genre with a continuous series is the version of Unis; although, it lacks the spells PT 206 and PT 208. Osing arranges these spells as a part of group (B) which begins on the north wall of the burial chamber, spills over to its east wall, and ends on the north wall of the passage between the burial chamber and antechamber [9]. Allen exclusively assigns these spells in sequence (D) [6], while Hays classifies them as a part of group $\mathrm{H}$ (Provisioning) [30]. These spells represent the offering-rituals which are addressed on behalf of the deceased king, invoking some celestial beings to provide the king with his meals. The editors of the postUnis pyramid texts corpora excluded PT 204 and PT 209 and integrated the other spells of this genre into another group. Also, they added PT 206 and PT 208 to the new composition which shows somewhat different locations. In this regard, PT 208, PT 210-212 are placed in the east wall of Merenre's burial chamber and the east gable of both Teti and Pepi II's burial chamber. Also, PT 206, which is not attested in Unis pyramid texts corpus, accompanies PT 208, PT 210-212 on the same location in the pyramids of both Merenre and Pepi II, while it is located on the east wall of Pepi I's ascending corridor. Furthermore, PT 212, attested twice, is placed on the east wall of both the burial chamber and the antechamber of Pepi I. In the middle kingdom, the entire spells of the genre PT 204-212 were also transmitted in short sequences in continuous and discontinuous strings. This transmission extended to ElQatta, Saqaara, Dahshur, Lisht, Asyut, and Abydos. Both the burial chambers of 'Ijj$m$-htp [16-17] and s-n-wsrt-' $n h$ at Lisht have PT 204-205, PT 207, and PT 209-212 in the same order of Unis pyramid texts $[6,42]$. Furthermore, two textual sources from the middle kingdom preceded the introductory spell of this genre by a title. In this regard, the stela (C20520) of $N h j$ from Abydos [16,39,54], which has the spells PT 204-205, PT 207, and PT 209210, attributed the spell PT 204 to the title $r 3 n(j) s w 3 \underline{d} w \underline{d h} . w$ (Recitation for making the alter flourish) [54]. It is similar to the title which preceded PT 204 on the interior back of the coffin of 'Imnj (S1Ba) [16] from Asyut which read as $s w 3 \underline{d} w \underline{d} \underline{h} w$ $n(j) s m$ hrj.t ntrr rdi.t shm $=f m$ pr.t-hrw (Making the alter of a man flourish in the necropolis that he has power over invocation-offerings) [55]. The latter seems to be the complete formula of this title which, as Lapp suggested, refers to the whole genre, not to PT 204 alone [55]. What should be 
noted is that the coffin (S1Ba) contains the entire genre PT 204-212 which is topographically distributed over it on two places; PT 204-210 are positioned on the coffin back, while PT 210-212 are placed on the coffin head. Also, it is noted that PT 208 is attested twice on the coffin of Imnj (S1Ba) [16], as mentioned above, and on the burial chamber of $N h 3$ (Q1Q) from El-Qatta [16] which has PT 204, PT 205, PT 207-210. Finally, the stela of $3 w-j b R^{c}$ $h r$ (CG.28106) from Dahshur contains a very short sequence PT 204-205 [16,39,56]. In the new kingdom, the spells of this genre are topographically distributed on Hatshepsut's southern hall of offerings which is located on the third terrace of her temple at Deir el-Bahari. PT 210-2012 are placed on the north wall, while PT 205, PT 207, and PT 209-2012 occupy the south wall [21]. These spells are accompanied by offering scenes depicting the procession of priests who present the offerings to Hatshepsut [57]. As a new composition, the spells of this genre are also combined into the book of the dead; chapter 178 [58]. Also, the eighteenth dynasty Theban chapel (TT39) has PT 204-205, 207, and 209-212 which are integrated with an offering list type A-B, according to Barta [59]. Type A-B corresponds to ninety pyramid texts of Unis' offering rituals on the north wall of his burial chamber [19]. In the Late Period, the editors of the tomb (TT36) of I Ibj at Asasif reselected the spells PT 205, PT 207, PT 208 and, PT 210-212. This reselection may have been influenced by that of Hatshepsut [21]. Also, the reselection of these spells continued in the twentyseventh dynasty tomb of $t 3 j-n j-n 3-h b w$ at Saqqara whose editors arranged PT 204210 in an uninterrupted sequence [21]. PT 210-212 were transmitted into the postUnis pyramid texts corpora whose editors may have considered them as a cohesive and independent unit. From the textual program of both Hatshepsut and 'Ibj, it seems to be that their editors also considered PT 210-212 as one and independent unit. This is also very clear through the topo- graphical distribution of these spells on the coffin S1Ba mentioned above. But it is still to ask one more important question; that is, why the other spells of this genre were not transmitted into the pyramids of Unis' successors? In fact, the editing processes, and the adaptation of the pyramid texts after the reign of Unis may answer this question. In this regard, these spells were replaced by the alternative group of spells PT 337-354 (offering ritual) which are similar in content and may have been derived from the same source. Besides, the editors of both Merenre and Pepi II pyramid texts corpora inserted PT 400 and PT 406 between those of this group [36]. Similarly, PT 208, PT 210-212 were rearranged together and interpolated within this group. The spells of this group are distributed in an interrupted series on the east gable of the burial chamber of Teti, Pepi II, and on the east wall of the burial chamber of Merenre. Contrariwise, the editors of Pepi I's pyramid texts corpus changed the location of the offering ritual theme and placing it on the east wall of the antechamber, and the east wall of the ascending corridor [30].

\subsection{Group 2B -PT 200}

Group 2B contains only PT 200 which is a part of the discontinues numbering genre PT 199, PT 32, PT.23, PT 25, and PT 200. This genre is located on the north wall of the passage between the burial chamber and the antechamber. Osing classifies this genre as a part of the group (B) that occupies the north wall of the burial chamber, the east gable of the burial chamber, and the north wall of the passage between the burial chamber and the antechamber [9]. Allen suggests another classification, putting this genre as a part of sequence (C) that fills the east wall of the burial chamber and the passage between the burial chamber and antechamber. He marks this genre as subsequence (C2). Moreover, Allen eliminates the spells of the east gable of the burial chamber and added to this sequence PT 244 which is located on the south wall of the passage between the burial chamber and the antechamber [6]. Obviously, PT 200 
is arranged with thematically homogenous spells PT 199, 23, 25, and PT 32. In this respect, the subject of both PT 23 and PT 32 is (the libation), while that of PT 199 is (the reversion of offering $w \underline{d} b$ htp.t $n \underline{t} r$ ). The subject of PT 200 is (censing), being the same as its preceding PT 25 which is also located on the first register of the north wall of Unis' burial chamber (PT 23-57). Thus, this most probably explains why PT 200 was not reused after Unis, for the editors may have preferred to use the spell PT 25 and did not find a need to reuse PT 200 which was considered as a tautology [29].

\subsection{Group 3A -PT 247-252}

Group 3A involves PT 247, PT 248, PT 249, PT 250, PT 251, and PT 252. They are a part of the genre PT 247-253 which is placed on the west gable of the antechamber. This genre is one of six genres that are classified by Osing in group (D) which occupies the entire walls of Unis' antechamber [9]. Allen identifies this genre as a part of the sequence (F1) which fills the west gable and the south wall of Unis' antechamber. According to Allen, this genre begins with PT 247 and ends with PT 258, while the sequence (F1) starts with PT 247 and ends with PT 272 [6]. On the other hand, Hays assigns these spells as a part of the Section (J.1 PT 247-272) and identifies them as spells of (Arrival among the Gods) [30]. In his classification, Allen recognizes the theme of this sequence (ascending to the sky). He considers that PT 247 is the beginning of this sequence, for it states the statement of "the emerging from the Duat" [6]. Among the spells of this genre, only PT 253 was separated from its location and integrated into a new one, finding its way to the south part of the west wall of Teti's antechamber. Later, this genre was entirely transmitted to the middle kingdom in short sequences including one or two spells. In that respect, it is entirely found on the south wall of the burial chamber of $s n-w s r t-{ }^{\complement} n h$ from Lisht $[16,42]$, on the east wall of the burial chamber of $s$-IS.t and on the coffin fragments of $s 3 . t-j b j$ from Dahshur [16,56]. As a separated spell, the introductory spell of this genre PT 247, is placed on the east wall of the burial chamber of $W s r[16,17]$ and on the stela of Imn-m-h3.t-snb [16], while PT 249 is found on the stela (C 20093), and the fragments of the coffins $\mathrm{Hu} 2$, Hu5 and Hu6 [16]. Moreover, PT 252 is found on the coffin of $s b k w-h r-h 3 b$ from Meir [16]. Besides, PT 249 and PT 251 are separately found on the north and south sides of the canopic box of hpjj- $n h . t j=f$ [16]. In short sequences from Thebes, PT 249-250 are found on the coffin T7C of Nbw-hr-rdj.t (Cairo 28024), while PT 252-253 are placed on the coffin T13C of smn-htp (Cairo 28126) [16,17]. None of the spells of this genre show titles in the middle kingdom. But the eighteenth dynasty tomb of Nht-Mjn (TT87) has titles preceding both PT 247 and PT 251 [19,30, 60] as follows:

*) PT 247 r3 $n(j) r d j(. t) p r$ 3h m sb3 m p.t Utterance of causing that an Akh goes forth from the gate in the sky.

*) PT $251 r 3 n(j) h p r N N m$ m $t r$ Utterance of the transformation of $\mathrm{NN}$ into a god.

From these titles, it is clear to assign the purpose of this genre. It is recited to give the king the ability to ascend from the gate of the sky as a god and an $a k h$. The variant of PT 247 is CT.349 which states "re" tm rdj it.t.t(w) hk $k$.w $n(j) z(j) m$ - $=\{m$ hrj.t ntr (Not letting the magic of a man be taken from him in the necropolis) bears the same meaning and purpose. On the other hand, the title of book of the dead; chapter 174 is derived from PT 247-250, and it reads as $r 3 n(j) r d j . t p r 3 h m s b 3{ }^{2} 3$ p.t (Utterance of causing an Akh to ascent from the great gate of the sky) [30]. Also, the false door of the Eighteenth Dynasty Theban chapel (TT39) has excerpts from PT 249 (266a-b) and PT 252 (272a-c) [19]. In the Late Period tomb of ššnk at Asasif, PT 247 is preceded PT 245-264 and is followed by the two short sequences PT 269-272, and 
PT 302-304 [21]. Obviously, the editor of the tomb of $\check{s} \check{s} n k$ at Asasif reselected some spells which represent all the spells of the subgroups or the subsequences of Osing's group (D) [9], Allen's sequence (F) [6], and Hays' group (J) [30] which occupy all the walls of Unis' antechamber and extend to the end of the south wall of the passage between the burial chamber and the antechamber (PT 245-246). In the Roman period, the hieratic papyrus of Ns-Imn which is known as Sękowski papyrus has also PT 251-252 with many changes in words and orthographies [61]. The editors of the post-Unis pyramid texts corpora excluded the genre PT 247-253, except PT 253, and they used instead of it an analogous and alternative genre devoted to the spirit of the king. The spells of the new genre were distributed, according to the classification of Hays [30], from the top to the bottom on the west wall of Pepi I's antechamber (esp. PT 473-487), while they were divided into two sections, like that of Unis, on the west gable and the west wall of the antechamber of Merenre (esp. PT 473-476) and Pepi II (esp. PT 473-487). In the pyramid of Teti, these similar and alternative spells are found on the north end of the antechamber west wall.

\subsection{Group 3B -PT 260 and PT 263}

Group 3B has only two spells PT 260 and PT 263. The first is the last spell of the genre PT 254-260 which occupies the west wall of Unis' antechamber and spans to its south wall, while the second is located on the south wall of Unis' antechamber as a part of genre PT 260-272. Both PT 260 and PT 263 belong to Osing's group (D) [9], while it is classified as subsequence (F1) and Section (J1) by Allen, and Hays, respectively. Also, they are related to the previous genre PT 247-253, quoted above, and has the same theme [6,30]. Except for PT 260, the other spells of the genre PT 254-260 were isolated and transferred to the west wall of Teti's antechamber. In the same way, PT 261-262, and PT 264-272 were also transferred to different locations in Unis post-pyramids [17]. The transmis- sion of these two spells to the middle kingdom was restricted to Dahshur and Lisht. Both PT 260 and PT 263 are attested in continuous series of the genre PT 260272 in the burial chamber of $s 3$-Is.t at Dahshur [16]. What is noted is that the editors of this burial chamber distributed PT 247-273 on its east, west, and south walls. Also, they are located on the south wall of the burial chamber of 'Ijj-m-htp in short series of spells PT 260-263, PT 267 and PT 270 which are separated from their companions' PT 268-272 by the genre PT 204-212 [16,17]. On the south wall of the burial tomb of $s n-w s r . t^{-} n h$ at Lisht [42], PT 260 is attested in continuous sequences PT 247-258 and PT 260-261. From the previous attestations, PT 260 and PT 263 connected with the genres PT 247-253, PT 254-260, PT 260-272, and PT 204-212. This is also confirmed in the Late Period tomb of P3-dj-Imn-jpt at Asasif whose editors reselected PT 245-267 [21]. Clearly, PT 264-266 are variants of PT 263 and they are similar in content. Their theme centralizes on ferrying the king over the sky. In postUnis tradition, the editors excluded PT 263 , preferring to use its alternative spells PT 264-266 which were transferred to the pyramid texts corpora of Teti and Pepi I [17, 30]. Furthermore, the spell PT 473 which is attested in the pyramids of Merenre and Pepi II is also thematically analogous of PT 263. As for PT 260, it is invoked to the god Geb - the bull of the sky - by the priest who states that the king, identified with Horus, reverted the throne of Geb, stopped the fight on Ōn, and overcame his enemies. PT 260 may have been eliminated by the editors of post-Unis pyramids because of its content and theme which are different from the other spells of this genre whose theme centers on the king's ascension to the sky and his arriving among the gods.

\subsection{Group 4A - PT 313, PT 314, PT 315, and $P T 317$}

Group 4A includes the genre PT 313317 which occupies the entire west wall of Unis' ascending corridor. This genre is classified by Osing as Group (E1) [9], 
Allen's Sequence (I) [6], and Hays' Section (L2) [30]. As Allen suggests, these spells visualize the king during his rising to the sky, for the inception spell of this genre states that j.wn ?.jj p.t (open the two doors of the sky) [6]. Hays identifies the group (L) as Transformation that begins on the north wall of Unis' antechamber (L.1: Assumption of the form of Horus) and continues on both the west wall of Unis' ascending corridor (L.2 beg: Assumption of theriomorphic forms) and the east wall of Unis' ascending corridor (L.2end: Assumption of theriomorphic forms) [30]. Except PT 316, the genre PT 313-317 was not transmitted into the post-Unis pyramid texts corpora. However, the spells of this genre were entirely transmitted to both the middle kingdom tomb of $s n$-wsrt- $n h$ [42] and the tomb chamber of 'Ijj-m-htp $[16,17]$ at Lisht. Furthermore, the last spell of this genre was also transmitted to the late period tomb of P3-dj-Imn-htp at Asasif (TT33) in a new sequence PT 317-320 [21]. The genre PT 313-317 is a clear example of the editing processes of the pyramid texts exclusion, modification, replacement, and alternation. The disappearance of this genre in postUnis pyramids connected with some changes about the theme and the location. Actually, the spells of the genre PT 313-317 centers on equipping the king to ascend to the sky, bearing many different themes: PT 313 (Opening the door of the sky), PT 314 (Protective spell against a bull), PT 315 (The king is a baboon greeting the sungod), PT 316 (The king demands the help to ascend to the sky), and PT 317 (The king is identified with the god Sobek). The texts' theme of the post-Unis pyramid texts inscribed on the ascending corridors mainly focus on the king's ascension and his joining with the god $\operatorname{Re}^{r}$ in the sky rather than the king's assumption of the theriomorphic forms. Obviously, the new alternative spells of the king's ascension and his joining with the god $\mathrm{Re}^{r}$ in the sky PT 503-535 became the theme of the texts of ascending corridors after Unis, especially those of Pepi I, Merenre and Pepi
II [30]. As a result, the genre PT 313-317 were replaced with the genre PT 503-535 which have the same theme and location.

\subsection{Group 4B - PT 319 and PT 320.}

Group 4B is a part of the genre PT 318321 which occupies the entire east wall of Unis' ascending corridor. This genre is classified by both Osing and Allen as group (E2) and Sequence (J) respectively $[9,6]$, while Hays identifies it as the previously mentioned section (L2 end) [30]. Only two spells of this genre PT 318, and PT 321 were transmitted into the post-Unis pyramid texts corpora with different locations. At this point, PT 318 was transferred twice to the east wall of Teti's antechamber, while PT 321 was transferred to the west wall of Pepi I's ascending corridor- north section [36]. On the other hand, both PT 319 and PT 320 were transmitted as members of the genre PT 318-319 to the middle kingdom burial chamber of both 'Ijj-m-htp and sk-wsht at Lisht and Saqqara [17]. In the late period, PT 319 and PT 320 were transmitted to the tomb of P3-dj-Imn-htp at Asasif (TT33), while the two lines of PT 320 (515a-516a) were transmitted to the exterior lid of king Aspelta's sarcophagus [21]. Noteworthy, the two genres PT 313-317 and PT 318-321 of Unis were abbreviated in the late period tomb of P3-dj-Imn-htp to the series PT 317-320 in the same manner of their arrangement in the burial chamber of ' $I j j-m$ - $h t p$ whose editors sequentially distributed the two genres PT 313-317 and PT 318-321 on the west wall. The latter matches the classification of Hays who arranges these two genres under the same theme (Assumption of theriomorphic forms). Also, Hussein noted that the editors of the late period tomb of $t 3-n-n b w$ at Saqqara rearranged PT 320 after the short sequence PT 67-270 [22] whose theme is (Ascending to the sky). The exclusion of PT 319 and PT 320 in the post-Unis old kingdom pyramid texts may be due to their theme which focuses, like PT 317318 , on theriomorphic forms of the king that helps him to ascend to the sky. In this respect, the king is identified with the bull with sunlight in each eye and with the baboon god Babi. 


\section{Results}

The pyramid texts corpus of Unis has 227 spells that were arranged and organized in many genres. Every genre consists of some spells that have the same theme and they form with the other genres the textual program of the pyramid. The spells of Unis pyramid texts corpus were transmitted to his post old kingdom pyramid texts corpora except 38 spells that are called by the author as "Un-transmitted spells". However, all the un-transmitted spells of Unis, those which were not circulated in the royal pyramids of the old kingdom, were reselected after the old kingdom except for PT 200. They found their way to the middle kingdom, the new kingdom, the late period, and even the Roman period, but were often integrated into short sequences with interrupted and uninterrupted order. In the old kingdom, the textual program of each pyramid was subjected to the editing processes by exclusion and inclusion some spells or genres based on many reasons. Concerning the "Un-transmitted spells" of Unis, the current study investigated the phenomenon of their un-transmission in the royal pyramids of the old kingdom. As a result, excluding some spells or entire genre depends on three suggested reasons: The first one is using new and alternative spells or genres instead of the un-transmitted ones. The second one is that the un-transmitted spells or genres lost their relevancy with the other genres since the spells or genres have a cohesive relation among them and with the other related genres. The third one is that the editors of the post-Unis pyramid texts corpora rearranged some of the spells inside the genres to be thematically homogeneous. It is noted that these three cases are sometimes accompanied by changing the location of the spells or genres inside the pyramid. Thus, changing the theme of a certain location inside the pyramid is sometimes the reason for exclusion of the archetype of spells for the new ones.

\section{Discussion}

The pyramid texts are read inside the pyramids in continuous sequences of genres
(Textual program) from the burial chamber to the ascending corridor towards the north. This textual program achieves the main goal of the pyramid texts and any change that was made in this program was subjected to the editing processes that do not contradict the aim of those texts. The main goal of the pyramid texts is to transform the deceased king from the state of death to be an $A k h$ imperishable star in the celestial world. Although the textual program varies from a pyramid to another, it takes the similar themes of genres that achieve the main goal. The editing processes of modification and maturation of the pyramid texts started from the reign of Teti to the end of the old kingdom by replacing, innovating, and changing the topographical distribution of the spells and genres. Every textual program was subjected to the editorial activities and processes of inclusion and exclusion of the genres which produced new sequences of spells that differ in size, content, location, and arrangement from the earlier ones.

\section{Conclusion}

Although some Egyptologists assumed that reselecting one or more spells probably reflect the principle of "Synecdoche" i.e. using a part of the genre, in a new composition, to represent the whole genre, it seems that it goes beyond this assumption. Cleary, the exclusion of some spells can be regarded as a process of the text's transmission. In other words, the un-transmission of specific spells of any genre is considered an implied process of this genre transmission and its re-edition.

\section{References}

[1] Schott, S., (1950). Bemerkungen zum altägyptischen kult, BABA 5/2, Wiesbaden.

[2] Painkoff, Al., (1968). The pyramid of Unis. texts with commentary, Bollingen Series XL. 5, Princeton Univ. Press, NY.

[3] Spiegel, J., (1971). Das aufersehenungsritual der Unas-pyramide, Band 23, Otto Harrassowitz, Wiesbaden.

[4] Osing, J., (1994). Zu spruch 534 der pyramidentexte, BdÉ, Vol. 106 (1), pp: 279-284. 
[5] Morales. A., (2017). The transmission of the pyramid texts of Nut: Analysis of their distribution and role in the old and middle Kingdom, SAK Beihefte 19, Helmut Buske, Hamburg.

[6] Allen, J., (1994). Reading a pyramid, $B d E$, Vol. 106 (1), pp: 5-28.

[7] Hays, H., (2009). Unreading a pyramid, BIFAO, Vol. 109, pp: 195-220.

[8] Barta, W., (1981). Die bedeutung der pyramidentexte für den verstorbenen könig, MÄS 39, Deutscher Kunstverlag, München.

[9] Osing, J., (1986). Zur disposition der pyramidentexte des Unas, MDAIK, Vol. 42, pp: 131-144.

[10] Allen, J., (1986). The pyramid texts of queens Jpwt and Wdbt.n(j), JARCE, Vol. 23, pp: 1-25.

[11] Beaux, N., (1994). La douat dans les texts des pyramides. Escape et temps de gestation, BIFAO, Vol. 94, pp: $1-6$.

[12] Hussein, R., (2017). Text transmission or text reproducing? The shifting materiality of the pyramid texts spell 267 , in: Bickel, S. \& Iglesias, L (eds.), Studies in Ancient Egyptian Funerary Literature, OLA 257, Leuven- Paris-, pp: 295-329.

[13] Barta, W., (1986). Die pyramidentexte auf den privatsärgen des mittleren reiches, Z̈̈S, Vol. 113 (2), pp: 1-8.

[14] Kahl, J., (1995). Das überliferungsgeschichte verhältnis von Unis und Sesostrisanch am beispiel von PT. 302312, SAK, Vol. 22, pp: 195-209.

[15] Thompson, S., (1990). The origin of the pyramid texts found on middle kingdom Saqqâra coffins, JEA, Vol. 76 (1), pp: 17-25.

[16] Morales, A., (2013). The transmission of the pyramid texts into the middle kingdom: philological aspects of a contionous tradition in egyptian mortuary literature, UMI 3565179, University of Pennsylvania, USA.

[17] Allen, J., (2006). The Egyptian coffin texts, volume 8: middle kingdom copies of pyramid texts, OIP 132, Chicago.
[18] Hays, H., (2006). The typological structure of the pyramid textsand its continuities with the middle kingdom mortuary literature, $\mathrm{PhD}$, Faculty of the Devision of the Candidacy for he Degree of doctor of Philosophy, Chicago.

[19] Hays, H. \& Schenck, W., (2007). Intersection of ritual space and ritual representations: pyramid texts in eighteenth dynasty theban tombs, in: Dorman, P. \& Bryan, B. (ed.) Sacred Space and Sacred Function in Ancient Thebes, SAOC 61, Chicago, pp: 97115.

[20] Ayad, M., (2003). The funerary texts of Ameniridis I: analysis of their layout and purpose, $\mathrm{PhD}$, Egyptology and Ancient West Asian Studies dept., Brown Univ., Providence.

[21] Ayad, M., (2003). Some remarks on the pyramid texts inscribed in the chapel of Ameniridis I at Medinet Habu, in: Thompson, S. E. \& Der Manuelian, P (ed.), Egypt and Beyond. Essays Presented to Leonard H. Lesko, Brown Univ., Providence, pp: 1-13.

[22] Hussein, R., (2009). The saite pyramid texts copies in the memphite and heliopolitan shaft-tombs: A study of their selection and layout, $\mathrm{PhD}$, Egyptology and Ancient West Asian Studies dept., Brown Univ., Providence.

[23] Hussein, R., (2013). Recontextualized - the pyramid texts 'serpent-spells' in the saite contexts, Études et Travaux, Vol. XXVI, pp: 274-290.

[24] Quack, J., (1994). Die lehren des Ani: ein neuägyptischer weisheitskeit in seinen kulturellen umfeld, OBO 141, Universitätsverlag, Fribourg, Switzerland

[25] Szczudlowska, A., (1973). Pyramids texts preserved on Sękowski papyrus, ZÄS, Vol. 99, pp: 25-29.

[26] Sliverman, D., (1989). Textual critsicim in the coffin texts, in: Simpson, W. (ed.) Religion and Philosophy in Ancient Egypt, YES 3, New Haven, pp: 30-53. 
[27] Schenkel, W., (1978). Das stemma der altägyptischen sonnenlitanie, grundlegung der textgeschichte nach der methode textkritik, Harrassowitz GOF IV/6, Wiesbaden.

[28] Zeidler, J., (1987). Das stemma des pfortenbuches, Harrassowitz Verlag, Tübingen.

[29] Altenmüller, H., (1972). Die texte zun begräbinsritual in den pyramiden des alten reiches, ÄA 24, O. Harrassowitz, Wiesbaden.

[30] Hays, H., (2012). The organization of the pyramid texts: Topology and disposition, $2 \mathrm{Vol}_{\mathrm{s}}$., $\operatorname{Pd} \ddot{\mathrm{A}}$ 31, Brill Leiden.

[31] Hays, H., (2009). Old kingdom sacerdotal texts, JEOL, Vol.41, pp: 47-94.

[32] Leitz, Ch., (1996). Die schlangenspruche in den pyramidentexten, Orientalia, Vol. 65, pp: 381-427.

[33] Sperveslage, G., (2013). Zu anbringung und umfeld der schlangensprüche in den pyramidentexten, Sokar, Vol. 27, pp: 38-51.

[34] Jéquier, G., (1936). Le monument funéraire de Pepi II, Services des Antiquités de l'Egypt, Fouilles á Sakkarah 13, Le Caire.

[35] Jéquier, G., (1933). Les pyramide des reins Neit et Apout, Services des Antiquités de l'Egypt, Fouilles á Sakkarah 10, Le Caire.

[36] Allen, J., (2013). A new concordance of the pyramid texts, I, Introduction. Occurrences. Transcription, AWOL, (https://books.google.com.eg/books/a bout/A_New_Concordance_of_the_P yramid_Texts.html?id=P8yqoAEAC AAJ\&redir_esc $=y$ ).

[37] Berger El-Naggar, C., Marie-Noëlle, F., (2008). Béhénou "aimée de Pepy" une nouvelle reine d' Égypte, BIFAO, Vol. 108, pp: 1-26.

[38] Leclant, J., Berger-el Naggar, C., Mathieu, B., et al., (2001). Les texts de la pyramide de Pepi Ier, description et analyse, MIFAO 118/1, Facsimilés, MIFAO 118/2, l'institut français d'archéologie orientale du Caire, Le Caire.
[39] Lesko, L., (1979). Index of the spells on Egyptian middle kingdom coffins and related documents, Berkeley, California.

[40] Chassinat, É., Gauthier, H. \& Pieron, H., (1906). Fouilles de Qattah, MIFAO 14, Institut Français d'archéologie orientale du Caire, Le Caire.

[41] Russo, B., (2004). Un ritual matinal dans la tombe du myoyen empire de Neha, RdÉ, Vol. 55, pp: 113-123.

[42] Hayes, W., (1973). The texts of the mastabeh of Se'n-woseret-'ankh at Lisht, Egyptian Expedition Pub. II, NY.

[43] Allen, J., (1996). Coffin texts from Lisht, in: Willems, H. O. (ed.), The World of the Coffin Texts, Proc. of the Symposium held on the Occasion of the $100^{\text {th }}$ Birthday of Adrian de Buck, The Netherlands Institute for the Near East, Leiden, pp. 1-15.

[44] Lapp, G., (1985). Särge des mittleren reiches aus der ehemaligen sammlung Khashaba, ÄA, Otto Harrassowitz, Wiesbaden.

[45] Dumichen, G., (2016). Der grabpalast des patuamenapt in der thebanischen nekropolis 3, Hansebooks, Leipzig.

[46] Allen, J., (1950). Occurrences of pyramid texts with cross indexes of these and other egyptian mortuary texts, SAOC 27, Chicago.

[47] Hussein, R., (2011). Notes on the saite copies of pyramid texts spells in the memphite and heliopolitan shafttombs", in: Hawas, Z., Daoud, Kh. A., \& Hussein, R. (eds.), Scribe of Justice. Egyptological Studies in honour of Shafik Allam, SASEA, Vol. 42, Le Caire, pp: 217-233.

[48] Meurer, G., (2002). Die feinde des konigs in den pyramidentexten, OBO 189, Universitätsverlag / Vandenhoeck \& Ruprecht Freiburg, Germany.

[49] Rusch, A., (1922). Die entwicklung der himmelsgöttin Nut zu einer totengotheit, MVAG 22, Hinrichs, Leipzig. 
[50] Faulkner, R., (1924). The cannibal hymn from the pyramid texts, JEA, Vol. 10, pp: 97-103.

[51] Barta, W., (1991). Zur mutilation tradiertertexte am beispiel des kannibalenhymnus, ZÄS, Vol. 118, pp: 10-20.

[52] Gobes, K., (2004). The cannibal spells: Continuity and change in the pyramid text and coffin text versions, $B d E$, Vol. 139, pp: 143-173.

[53] Eyre, Ch., (2002). The cannibal hymn. A culture and literary study, Liverpool Univ. Press, Liverpool.

[54] Lange, H. \& Schäfer, H., (1902). Grabund denksteine des mittleren reiches im museum von Kairo, CG.20001-20780, Reichsdruckerei, Berlin.

[55] Lapp, G., (1986). Der sarg des jmnj mit einem spruchgut am übergang von sargtexten zum totenbuch, $S A K$, Vol. 13, pp: 137-145.
[56] De Morgan, J., (1895). Fouillesà Dahchur, I, Holzhausen, Vienna.

[57] Naville, E., (1901). The temple of Deir el Bahari, IV: The shrine of Hathor and the southern hall of offerings, MEEF XIX, London.

[58] Allen, T., (1974). The book of the dead or going forth by day, SAOC 37, Chicago.

[59] Winfried, B., (1963). Die altägyptische opferliste von der frühzeit bis griechisch-römischen epoche, MÄS 3, Verlag Bruno Hessling, Belrin.

[60] Guksch, H. (1995). Die gräber des Nacht-Min und des Men-Cheper-Raseneb. Theben Nr.87 und 79, AV 34, P. von Zabern, Mainz.

[61] Szczudlowska, A., (1972). Liturgical text preserved on sękowski papyrus, Z̈̈S, Vol. 98, pp: 50-80. 